\title{
INFRAFRONTIER: a European resource for studying the functional basis of human disease
}

\author{
Michael Raess ${ }^{1}$ - Ana Ambrosio de Castro ${ }^{1}$ • Valérie Gailus-Durner ${ }^{2}$. \\ Sabine Fessele $^{1} \cdot$ Martin Hrabě de Angelis $^{1,2} \cdot$ the INFRAFRONTIER Consortium
}

Received: 4 March 2016/Accepted: 14 April 2016/Published online: 4 June 2016

(c) The Author(s) 2016. This article is published with open access at Springerlink.com

\begin{abstract}
Ageing research and more generally the study of the functional basis of human diseases profit enormously from the large-scale approaches and resources in mouse functional genomics: systematic targeted mutation of the mouse genome, systemic phenotyping in mouse clinics, and the archiving and distribution of the mouse resources in public repositories. INFRAFRONTIER, the European research infrastructure for the development, systemic phenotyping, archiving and distribution of mammalian models, offers access to sustainable mouse resources for biomedical research. INFRAFRONTIER promotes the global sharing of high-quality resources and data and thus contributes to data reproducibility and animal welfare. INFRAFRONTIER puts great effort into international standardisation and quality control and into technology development to improve and expand experimental protocols, reduce the use of animals in research and increase the reproducibility of results. In concert with the research community and the International Mouse Phenotyping Consortium (IMPC), INFRAFRONTIER is currently developing new pilot platforms and services for the research on ageing and age-related diseases.
\end{abstract}

Martin Hrabě de Angelis

hrabe@helmholtz-muenchen.de

INFRAFRONTIER GmbH, 85764 Neuherberg, Germany

2 Institute of Experimental Genetics \& German Mouse Clinic, Helmholtz Zentrum München, 85764 Neuherberg, Germany

\section{Comprehensive analysis of ageing phenotypes in a mouse clinic}

Neff et al. (2013) recently reported on a large-scale study to test whether the extended lifespans of mice treated with the drug rapamycin (Harrison et al. 2009; Miller et al. 2011) can be attributed to direct rapamycin effects on ageing. They used the unique setup of the German Mouse Clinic (www.mouseclinic.de), which allows to comprehensively study the effects of genotypes, environmental factors or treatments on phenotypes (Fuchs et al. 2012; Gailus-Durner et al. 2005, 2009), to carry out a comprehensive analysis of rapamycin effects on more than 150 ageing phenotypes across 25 different tissues in male C57BL/6 J mice. The study, which was carried out in cooperation with the German Center for Neurological Diseases (DZNE), analysed three cohorts of mice on rapamycin supplemented diets starting in early adulthood (4 months), midlife (13 months) and late in life (20-22 months). Each cohort was treated for at least 12 months before a comprehensive phenotypic analysis was performed (starting at 16, 25 and 34 months of age, respectively). Those ageing phenotypes rescued by rapamycin were further assessed in groups of young adult mice to identify ageing-independent rapamycin effects.

As in previous studies, Neff et al. (2013) observed that rapamycin extended lifespan in the treated mice. There was, however, no systematic effect of the drug on ageing phenotypes, since only a subset of traits was rescued by rapamycin. Moreover, many of those traits were equally affected by rapamycin in young mice, suggesting ageingindependent drug effects. The authors therefore conclude that the effects of rapamycin on longevity are not necessarily mediated by direct effects on ageing traits but could 
rather be the results of a reduction of life-limiting pathologies such as specific cancers by rapamycin.

The study by Neff and colleagues exemplifies the strength of the mouse clinic concept, which allows obtaining a truly systemic understanding of how disease phenotypes are affected by the genetic make-up, lifestyle or treatment regime (or a combination of those). Researchers who want to test their hypothesis on how ageing is affected by specific treatments or challenges can plan, design and initiate the experiments in their own facilities, where the setup of the cohorts, breeding and ageing can be done. The comprehensive phenotypic analysis is then carried out by the mouse clinic, and researchers profit from the extensive expert knowledge, sophisticated high-end technology and tailormade statistical analysis offered by these large-scale phenotyping facilities. European mouse clinics offering a standardised first-line phenotyping screen are located in Germany (German Mouse Clinic, Munich), France (Institute Clinique de la Souris, Strasbourg) and the United Kingdom (Mary-Lyon Centre, Harwell and Wellcome Trust Sanger Institute, Hinxton). A novel mouse clinic is currently becoming operative in the Czech Republic (Czech Centre for Phenogenomics, Prague). All these European mouse clinics are organised in the INFRAFRONTIER network (www. infrafrontier.eu, see below). Modelled on these successful examples, mouse clinics meanwhile also operate in North America, Asia and Australia.

\section{European large-scale functional genomics initiatives and the INFRAFRONTIER research infrastructure}

Mouse studies like the one of Neff and colleagues help discover the functional basis of ageing-related diseases and other human disease conditions (Fuchs et al. 2011; Schughart et al. 2012; Vandamme 2015) and are also important in preclinical screening (Varga et al. 2010) and drug development (Neschen et al. 2015; Sharpless and Depinho 2006; Zambrowicz and Sands 2003). As exemplified by the mouse clinic concept, Europe has played a leading role, both in the initiation of large-scale approaches for functional mouse genomics and in the continuous cross-laboratory standardisation of operation procedures and quality measures that allowed them to evolve into truly global scientific enterprises (Beckers et al. 2009; Rosenthal and Brown 2007).

Using a combination of gene trapping and gene targeting the European Conditional Mouse Mutagenesis Program (EUCOMM) as part of the International Knock-Out Mouse Consortium (IKMC) created a resource of mutated ES cells and mice for each protein-coding gene in the mammalian genome (Collins et al. 2007; Friedel et al. 2007). Drawing on this resource, a consortium of European mouse clinics participating in the EUMODIC initiative (European Mouse Disease Clinic) showed that it is feasible and also scalable to carry out a multi-laboratory programme for the broadbased phenotypic analysis of mammalian gene function (Angelis et al. 2015; Morgan et al. 2010). The success of this programme led to the initiation of the International Mouse Phenotyping Consortium (IMPC, www.mousephe notype.org), which brought large-scale phenotyping to the global level, with the aim to create an openly accessible catalogue of mammalian gene function (Brown and Moore 2012; Koscielny et al. 2014).

At the same time as the large-scale approaches for the mutagenesis and systemic phenotyping of mice were developed, a consortium of European research centres started to build the European Mouse Mutant Archive (EMMA), a repository that archives and distributes mutant mouse lines submitted by individual researchers and generated by the large-scale initiatives IKMC and IMPC (Hagn et al. 2007). Starting in 2001, the EMMA repository has been continually growing (Fig. 1a) and currently is the third largest repository for mouse strains listed on the $I n$ ternational Mouse Strain Resource (www.findmice.org/ repository) (Eppig et al. 2015), distributing mouse strains to biomedical researchers around the globe (Fig. 1b).

Building sufficient capacities and securing sustainable access to high-quality resources for mouse functional genomics across national borders is a challenge that requires novel funding and governance models (Mishra et al. 2016). In Europe, therefore, a consortium of 23 research centres across 15 countries established the panEuropean INFRAFRONTIER Research Infrastructure for the generation, systemic phenotyping, archiving and distribution of mouse disease models. The INFRAFRONTIER partners are mouse clinics and EMMA archiving and distribution centres. They offer an integrated portfolio of resources and services that can be accessed via a central web portal (www.infrafrontier.eu, Meehan et al. 2015) (Fig. 2). In 2015, more than 1300 user projects were handled by the INFRAFRONTIER Research Infrastructure.

The strategic importance of having available a sustainable resource for functional mouse genomics in Europe was underlined by the inclusion of INFRAFRONTIER on the first Roadmap of the European Strategy Forum on Research Infrastructures (ESFRI) issued in 2006 (www. esfri.eu). This document lists those pan-European research infrastructures that are crucial for building the European research area (ERA) and keeping a competitive edge to European science. According to the ESFRI definition, research infrastructures "are facilities, resources or services of a unique nature that have been identified by European research communities to conduct top-level activities in all fields. This...covers major equipment or sets of instruments, in addition to knowledge-containing 


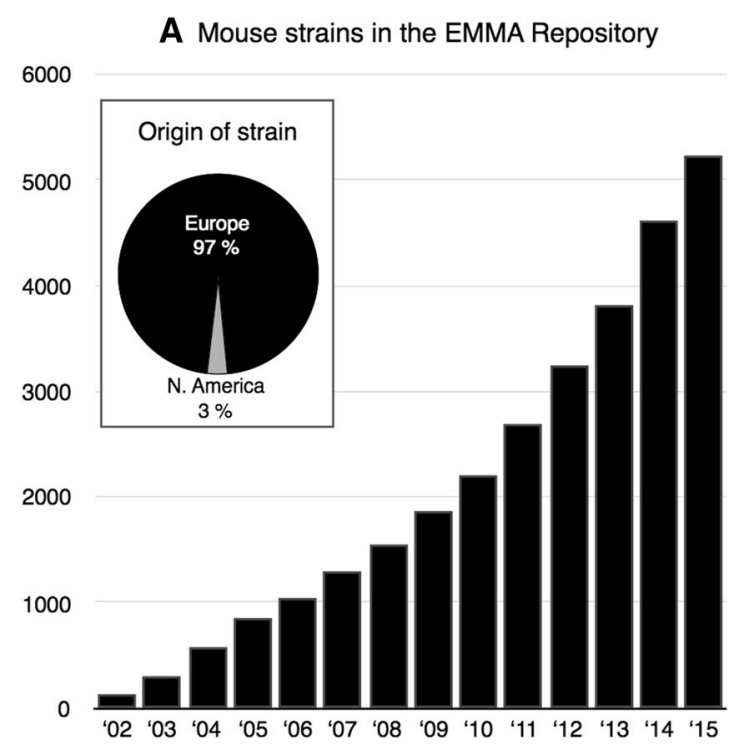

Fig. 1 a The European Mouse Mutant Archive (EMMA) as part of the INFRAFRONTIER Research Infrastructure is worldwide the third largest public repository of mutant mouse strains, with more than 5000 strains available. b The number of yearly requests for mouse strains in the EMMA repository is continuously growing. Almost half
B Annual requests from the EMMA Repository

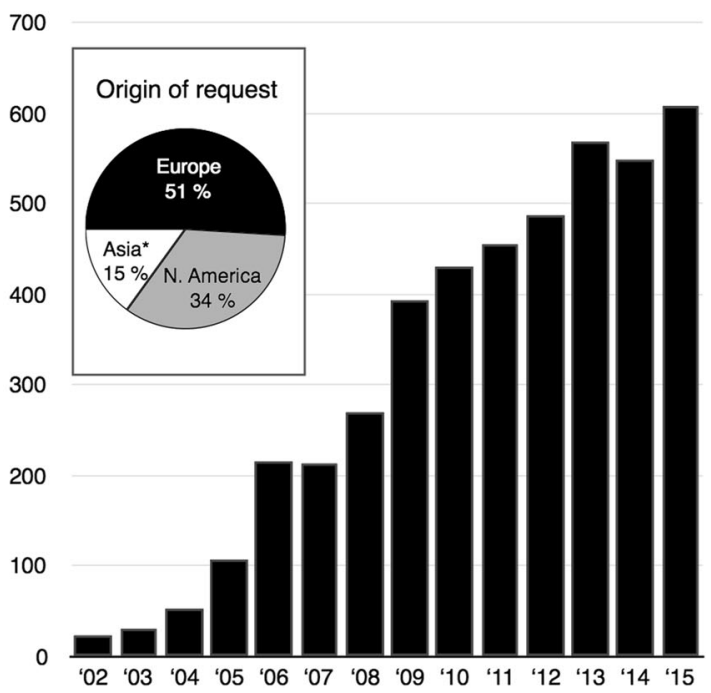

of the requests come from outside Europe. Mouse lines deposited by the large-scale initiatives IKMC/IPMC are in high demand and constituted approximately $50 \%$ of all requests in 2015. Asterisk Including requests from Oceania and Australia
Fig. 2 The resources and services of the

INFRAFRONTIER Research Infrastructure can be accessed at the central web portal. They are provided by the European INFRAFRONTIER partners and centrally coordinated by the INFRAFRONTIER GmbH/ ERIC (see text for further explanations)

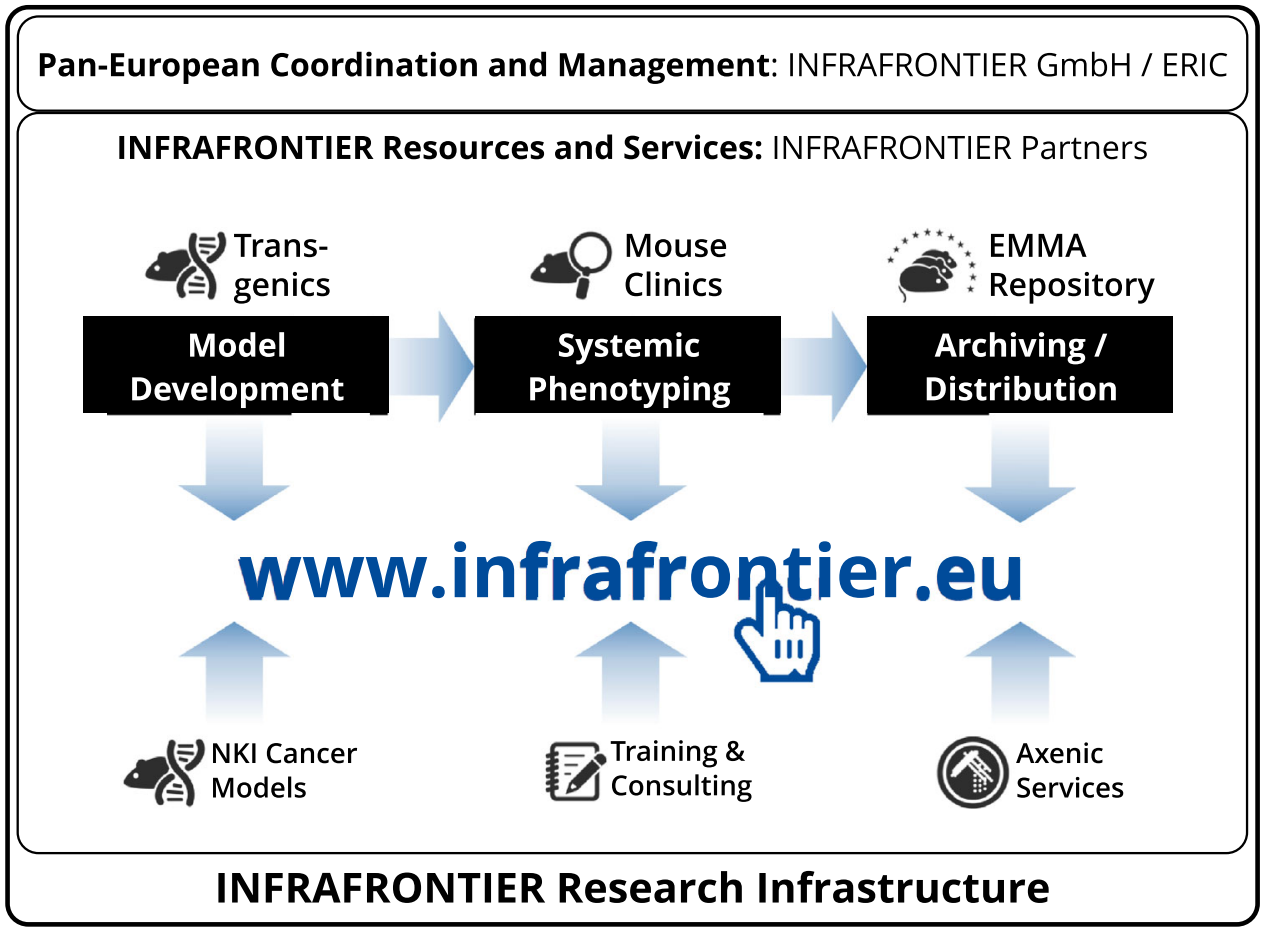

resources such as collections, archives and data banks". ESFRI also recognised that a sustainable pan-European organisation and governance is required to efficiently manage capacities and access to resources and services, particularly if the research infrastructure is distributed across several European countries. Therefore, in 2013 the INFRAFRONTIER GmbH was established to act as the central management unit of the INFRAFRONTIER Research Infrastructure. Meanwhile the process has been initiated to transform the INFRAFRONTIER GmbH into a European Research Infrastructure Consortium (ERIC), a legal form particularly created by the European Commission for pan-European research infrastructures like INFRAFRONTIER. In the fourth iteration of the ESFRI 
Roadmap which has been recently published, the INFRAFRONTIER Research Infrastructure is highlighted as one of the 'Landmark Projects'.

\section{INFRAFRONTIER helps improve animal welfare and data reproducibility}

Biomedical research infrastructures like INFRAFRONTIER play a key role in preserving and sharing resources and data created by publicly funded research (Mishra et al. 2016). By offering open access to centralised high-quality resources, they help prevent duplication of efforts and wasting of public resources. By setting standard operation procedures and strict quality control measures, they help reduce the irreproducibility of scientific results in preclinical research, the costs of which have been recently estimated to be 28 billion \$ per year in the US alone (Freedman et al. 2015).

In the case of the INFRAFRONTIER Research Infrastructure, this has direct implications on animal welfare and on the validity of scientific results based on studies in mice, which often suffer from poorly applied scientific standards (Perrin 2014; Justice and Dhillon 2016). The INFRAFRONTIER partners are strongly committed to the implementation of the $3 \mathrm{R}$ 's principle (replacement, reduction, refinement; Sabaté 2015) and do endorse the ARRIVE (Animal Research: Reporting of In Vivo Experiments) Guidelines which are promoted by the National Centre for Replacement, Refinement \& Reduction of animals in Research (www.nc3rs.org.uk/ARRIVE). Applying and reporting strict scientific quality standards is even more important with the spread of novel gene editing technologies like CRISPR/Cas9. Gene editing may make mouse mutant generation more generally accessible, but experience in mouse genetics is required to take into account the effects of genetic background, additional mutations and husbandry conditions such as housing, diet or the gut microbiome (Ericsson et al. 2015; Lloyd et al. 2015). Moreover, genotypes may get lost due to breeding errors or fatal diseases in the mouse colony. More than once experimental results could not be reproduced because the genotype could not be maintained. Public repositories such as INFRAFRONTIER/ EMMA have both the experience and the quality measures in place to safeguard scientifically valuable mouse strains.

The INFRAFRONTIER Research Infrastructure and its international partners put a lot of effort into the development of new technologies that help reduce animal numbers and refine existing animal experiments. Improving quality control by means of blastocyst genotyping reduces the number of animals required for cryopreservation, as well as processing time, technical requirements and costs (Scavizzi et al. 2015). Moreover, the methods described can also be applied to optimise experimental design when using CRISPR/Cas9 technologies in mouse model generation. Improving in vitro fertilisation technology and using refined cryoprotective agents is another way to reduce animal numbers and overall costs (Guan et al. 2014). INFRAFRONTIER technology development also focuses on the improvement of transportation procedures of mouse sperm and embryos (Kenyon et al. 2014). Coupled with training activities to enable INFRAFRONTIER users to work with frozen material, these activities have helped to markedly reduce the need for shipping live animals from the EMMA repository.

Overall, the INFRAFRONTIER Research Infrastructure has established a successful model "for sharing animal models, protocols and genetic information, as well as a wealth of cross-referenced data", and promotes transparency in animal research, as has been recently recognised by McGrath et al. (2015).

\section{Perspectives for ageing research}

Ageing research addresses a major societal challenge. As life expectancy increases globally, also the related health care costs for age-related diseases surge. Publicly funded research infrastructures have a public service mission to address these challenges. The INFRAFRONTIER Research Infrastructure does this in several ways: On the strategic level, INFRAFRONTIER engages with European programmes addressing ageing and age-related diseases, such as the joint programming initiatives "More Years, Better Lives" or the "EU Joint Programme-Neurodegenerative Disease Research (JPND)". On the scientific level, INFRAFRONTIER currently interfaces with the European ageing community to develop pilot platforms and services for ageing research that can be offered at the European level. These activities are tightly integrated with the current efforts of the International Mouse Phenotyping Consortium to set up a standardised ageing pipeline. The INFRAFRONTIER Research Infrastructure, in concert with the global large-scale resources for mouse functional genomics, already has a lot to offer to the biomedical research community for ageing, and it will put a lot of effort into expanding this even further in the coming years.

Open Access This article is distributed under the terms of the Creative Commons Attribution 4.0 International License (http://crea tivecommons.org/licenses/by/4.0/), which permits unrestricted use, distribution, and reproduction in any medium, provided you give appropriate credit to the original author(s) and the source, provide a link to the Creative Commons license, and indicate if changes were made. 


\section{References}

Beckers J, Wurst W, de Angelis MH (2009) Towards better mouse models: enhanced genotypes, systemic phenotyping and envirotype modelling. Nat Rev Genet 10:371-380

Brown SD, Moore MW (2012) The International Mouse Phenotyping Consortium: past and future perspectives on mouse phenotyping. Mamm Genome 23:632-640

Collins FS, Rossant J, Wurst W, International Mouse Knockout Consortium (2007) A mouse for all reasons. Cell 128:9-13

de Angelis MH, Nicholson G, Selloum M, White JK, Morgan H, Ramirez-Solis R, Sorg T, Wells S, Fuchs H, Fray M, Adams DJ, Adams NC, Adler T, Aguilar-Pimentel A, Ali-Hadji D, Amann G, André P, Atkins S, Auburtin A, Ayadi A, Becker J, Becker L, Bedu E, Bekeredjian R, Birling MC, Blake A, Bottomley J, Bowl MR, Brault V, Busch DH, Bussell JN, Calzada-Wack J, Cater H, Champy MF, Charles P, Chevalier C, Chiani F, Codner GF, Combe R, Cox R, Dalloneau E, Dierich A, Di Fenza A, Doe B, Duchon A, Eickelberg O, Esapa CT, Fertak LE, Feigel T, Emelyanova I, Estabel J, Favor J, Flenniken A, Gambadoro A, Garrett L, Gates H, Gerdin AK, Gkoutos G, Greenaway S, Glasl L, Goetz P, Da Cruz IG, Götz A, Graw J, Guimond A, Hans W, Hicks G, Hölter SM, Höfler H, Hancock JM, Hoehndorf R, Hough T, Houghton R, Hurt A, Ivandic B, Jacobs H, Jacquot S, Jones N, Karp NA, Katus HA, Kitchen S, Klein-Rodewald T, Klingenspor M, Klopstock T, Lalanne V, Leblanc S, Lengger C, le Marchand E, Ludwig T, Lux A, McKerlie C, Maier H, Mandel JL, Marschall S, Mark M, Melvin DG, Meziane H, Micklich K, Mittelhauser C, Monassier L, Moulaert D, Muller S, Naton B, Neff F, Nolan PM, Nutter LM, Ollert M, Pavlovic G, Pellegata NS, Peter E, Petit-Demoulière B, Pickard A, Podrini C, Potter P, Pouilly L, Puk O, Richardson D, Rousseau S, Quintanilla-Fend L, Quwailid MM, Racz I, Rathkolb B, Riet F, Rossant J, Roux M, Rozman J, Ryder E, Salisbury J, Santos L, Schäble KH, Schiller E, Schrewe A, Schulz H, Steinkamp R, Simon M, Stewart M, Stöger C, Stöger T, Sun M, Sunter D, Teboul L, Tilly I, Tocchini-Valentini GP, Tost M, Treise I, Vasseur L, Velot E, Vogt-Weisenhorn D, Wagner C, Walling A, Wattenhofer-Donze $\mathrm{M}$, Weber $\mathrm{B}$, Wendling $\mathrm{O}$, Westerberg $\mathrm{H}$, Willershäuser $\mathrm{M}$, Wolf E, Wolter A, Wood J, Wurst W, Yildirim AÖ, Zeh R, Zimmer A, Zimprich A; EUMODIC Marschall S, Raspa M, Pickard A, Takeo T, Nakagata N, Fray M. Consortium, Holmes C, Steel KP, Herault Y, Gailus-Durner V, Mallon AM, Brown, SD (2015) Analysis of mammalian gene function through broadbased phenotypic screens across a consortium of mouse clinics. Nature Genet 47(9), 969-978

Eppig JT, Motenko H, Richardson JE, Richards-Smith B, Smith CL (2015) The International Mouse Strain Resource (IMSR): cataloging worldwide mouse and ES cell line resources. Mamm Genome 26(9-10):448-455

Ericsson AC, Davis JW, Spollen W, Bivens N, Givan S, Hagan CE et al (2015) Effects of vendor and genetic background on the composition of the fecal microbiota of inbred mice. PLoS One 10(2):e0116704

Freedman LP, Cockburn IM, Simcoe TS (2015) The economics of reproducibility in preclinical research. PLoS Biol 13(6): e1002165

Friedel R, Seisenberger C, Kaloff C, Wurst W (2007) EUCOMMthe European Conditional Mouse Mutagenesis Program. Brief Funct Genom Proteom 6:180-185

Fuchs H, Gailus-Durner V, Adler T, Aguilar-Pimentel JA, Becker L, Calzada-Wack J, Da Silva-Buttkus P, Neff F, Götz A, Hans W, Hölter SM, Horsch M, Kastenmüller G, Kemter E, Lengger C, Maier H, Matloka M, Möller G, Naton B, Prehn C, Puk O, Rácz I, Rathkolb B, Römisch-Margl W, Rozman J, Wang-Sattler R,
Schrewe A, Stöger C, Tost M, Adamski J, Aigner B, Beckers J, Behrendt H, Busch DH, Esposito I, Graw J, Illig T, Ivandic B, Klingenspor M, Klopstock T, Kremmer E, Mempel M, Neschen S, Ollert M, Schulz H, Suhre K, Wolf E, Wurst W, Zimmer A, de Angelis MH (2011) Mouse phenotyping. Methods 53:120-135

Fuchs H, Gailus-Durner V, Neschen S, Adler T, Afonso LC, AguilarPimentel JA, Becker L, Bohla A, Calzada-Wack J, Cohrs C, Dewert A, Fridrich B, Garrett L, Glasl L, Götz A, Hans W, Hölter SM, Horsch M, Hurt A, Janas E, Janik D, Kahle M, Kistler M, Klein-Rodewald T, Lengger C, Ludwig T, Maier H, Marschall S, Micklich K, Möller G, Naton B, Prehn C, Puk O, Rácz I, Raess M, Rathkolb B, Rozman J, Scheerer M, Schiller E, Schrewe A, Steinkamp R, Stöger C, Sun M, Szymczak W, Treise I, Vargas Panesso IL, Vernaleken AM, Willershäuser M, WolffMuscate A, Zeh R, Adamski J, Beckers J, Bekeredjian R, Busch DH, Eickelberg O, Favor J, Graw J, Höfler H, Höschen C, Katus H, Klingenspor M, Klopstock T, Neff F, Ollert M, Schulz H, Stöger T, Wolf E, Wurst W, Yildirim AÖ, Zimmer A, de Angelis MH (2012) Innovations in phenotyping of mouse models in the German Mouse Clinic. Mamm Genome 23:611-622

Gailus-Durner V, Fuchs H, Becker L, Bolle I, Bielmeier M, CalzadaWack J, Elvert R, Erhardt N, Dalke C, Franz TJ, GrundnerCulemann E, Hammelbacher S, Hölter S, Hölzlwimmer G, Horsch M, Javaheri A, Kalaydjiev S, Klempt M, Kling E, Kunder S, Lengger C, Lisse T, Mijalski T, Naton B, Pedersen V, Prehn C, Przemeck G, Racz I, Reinhard C, Reitmeir P, Schneider I, Schrewe A, Steinkamp R, Zybill C, Adamski J, Beckers J, Behrendt H, Favor J, Graw J, Heldmaier G, Höfler H, Ivandic B, Katus H, Kirchhof P, Klingenspor M, Klopstock T, Lengeling A, Müller W, Ohl F, Ollert M, Quintanilla-Martinez L, Schmidt J, Schulz H, Wolf E, Wurst W, Zimmer A, Busch DH, de Angelis MH (2005) Introducing the German Mouse Clinic: Open access platform for standardized phenotyping. Nat Methods 2:403-404

Gailus-Durner V, Fuchs H, Adler T, Aguilar Pimentel A, Becker L, Bolle I, Calzada-Wack J, Dalke C, Ehrhardt N, Ferwagner B, Hans W, Hölter SM, Hölzlwimmer G, Horsch M, Javaheri A, Kallnik M, Kling E, Lengger C, Mörth C, Mossbrugger I, Naton B, Prehn C, Puk O, Rathkolb B, Rozman J, Schrewe A, Thiele F, Adamski J, Aigner B, Behrendt H, Busch DH, Favor J, Graw J, Heldmaier G, Ivandic B, Katus H, Klingenspor M, Klopstock T, Kremmer E, Ollert M, Quintanilla-Martinez L, Schulz H, Wolf E, Wurst W, de Angelis MH (2009) Systemic first-line phenotyping. Methods Mol Biol 530:463-509

Guan M, Bogani D, Marschall S, Raspa M, Takeo T, Nakagata N, Taft R, Fray M (2014) Contemporary techniques for freezing mouse spermatozoa. Curr Protoc Mouse Biol 4(3):85-104

Hagn M, Marschall S, de Angelis MH (2007) EMMA-the European mouse mutant archive. Brief Funct Genom Proteom 6:186-192

Harrison DE, Strong R, Sharp ZD, Nelson JF, Astle CM, Flurkey K, Nadon NL, Wilkinson JE, Frenkel K, Carter CS, Pa Marschall S, Raspa M, Pickard A, Takeo T, Nakagata N, Fray MHM, Javors MA, Fernandez E, Miller RA (2009) Rapamycin fed late in life extends lifespan in genetically heterogeneous mice. Nature 460:392-395

Justice MJ, Dhillon P (2016) Using the mouse to model human disease: increasing validity and reproducibility. Dis Model Mech 9:101-103

Kenyon J, Guan M, Bogani D, Marschall S, Raspa M, Pickard A, Takeo T, Nakagata N, Fray M (2014) Transporting mouse embryos and germplasm as frozen or unfrozen materials. Curr Protoc Mouse Biol 4:47-65

Koscielny G, Yaikhom G, Iyer V, Meehan TF, Morgan H, AtienzaHerrero J, Blake A, Chen CK, Easty R, Di Fenza A, Fiegel T, Grifiths M, Horne A, Karp NA, Kurbatova N, Mason JC, Matthews P, Oakley DJ, Qazi A, Regnart J, Retha A, Santos LA, 
Sneddon DJ, Warren J, Westerberg H, Wilson RJ, Melvin DG, Smedley D, Brown SD, Flicek P, Skarnes WC, Mallon AM, Parkinson H (2014) The International Mouse Phenotyping Consortium Web Portal, a unified point of access for knockout mice and related phenotyping data. Nucleic Acids Res 42:D802D809

Lloyd K, Franklin C, Lutz C, Magnuson T (2015) Reproducibility: use biobanks or lose them. Nature 522:151-153

McGrath JC, McLachlan EM, Zeller R (2015) Transparency in research involving animals: the basel declaration and the new principles for reporting research in BJP manuscripts. $\mathrm{Br} \mathrm{J}$ Pharmacol 172:2127-2432

Meehan TF, Chen CK, Koscielny G, Relac M, Wilkinson P, Flicek P, Parkinson H, Castro A, Fessele S, Steinkamp R, Hagn M, Raess M, de Angelis MH, Bottomley J, Ramirez-Solis R, Smedley D, Ball S, Blake A, Fray M, Kenyon J, Mallon AM, Brown S, Massimi M, Matteoni R, Tocchini-Valentini G, Herault Y, Kollias G, Fleming A, Ulfhake B, Demengeot J, Fremond C, Bosch F, Montoliu L, Soininen R, Schughart K, Brakebusch C, Sedlacek R, Rülicke T, McKerlie C, Malissen B, Iraqi F, Jonkers J, Russig H, Huylebroeck D (2015) INFRAFRONTIERproviding mutant mouse resources as research tools for the international scientific community. Nucleic Acids Res 43: D1171-D1175

Miller RA, Harrison DE, Astle CM, Baur JA, Boyd AR, de Cabo R, Fernandez E, Flurkey K, Javors MA, Nelson JF, Orihuela CJ, Pletcher S, Sharp ZD, Sinclair D, Starnes JW, Wilkinson JE, Nadon NL, Strong R (2011) Rapamycin, but not resveratrol or simvastatin, extends life span of genetically heterogeneous mice. J Gerontol A 66:191-201

Mishra A, Schofield PN, Bubela TN (2016) Sustaining large-scale infrastructure to promote pre-competitive biomedical research: lesson from mouse genomics. New Biotechnol 2:280-294

Morgan H, Beck T, Blake A, Gates H, Adams N, Debouzy G, Leblanc $\mathrm{S}$, Lengger $\mathrm{C}$, Maier H, Melvin D, Meziane H, Richardson D, Wells S, White J, Wood J, EUMODIC Consortium, Hrabě de Angelis M, Brown SD, Hancock JM, Mallon AM (2010) EuroPhenome: a repository for high-throughput mouse phenotyping data. Nucleic Acids Res 38:D577-D585

Neff F, Flores-Dominguez D, Ryan DP, Horsch M, Schröder S, Adler T, Afonso LC, Aguilar-Pimentel JA, Becker L, Garrett L, Hans W, Hettich MM, Holtmeier R, Hölter SM, Moreth K, Prehn C,
Puk O, Rácz I, Rathkolb B, Rozman J, Naton B, Ordemann R, Adamski J, Beckers J, Bekeredjian R, Busch DH, Ehninger G, Graw J, Höfler H, Klingenspor M, Klopstock T, Ollert M, Stypmann J, Wolf E, Wurst W, Zimmer A, Fuchs H, GailusDurner V, de Angelis MH, Ehninger D (2013) Rapamycin extends murine lifespan but has limited effects on aging. J Clin Invest 123:3272-3291

Neschen S, Scheerer M, Seelig A, Huypens P, Schultheiss J, Wu M, Wurst W, Rathkolb B, Suhre K, Wolf E, Beckers J, de Angelis MH (2015) Metformin supports the antidiabetic effect of a sodium glucose cotransporter 2 inhibitor by suppressing endogenous glucose production in diabetic mice. Diabetes 64:284-290

Perrin S (2014) Preclinical research: make mouse studies work. Nature 507:423-425

Rosenthal N, Brown S (2007) The mouse ascending: perspectives for human disease models. Nat Cell Biol 9:993-999

Sabaté D (2015) Ethical Issues and regulations and guidelines concerning animal research. In: Mannhold R, Kubinyi H, Folkers $\mathrm{G}$ (ed) In vivo models for drug discovery 62: 90-112, WilleyVCH, pp 91-106

Scavizzi F, Ryder E, Newman S, Raspa M, Gleeson D, Wardle-Jones H, Montoliu L3, Fernandez A, Dessain ML, Larrigaldie V, Khorshidi Z, Vuolteenaho R, Soininen R, André P, Jacquot S, Hong Y, de Angelis MH, Ramirez-Solis R, Doe, B (2015) Blastocyst genotyping for quality control of mouse mutant archives: an ethical and economical approach. Transgenic Res 21, 921-927

Schughart K, Libert C, SYSGENET consortium, Kas MJ (2012) Controlling complexity: the clinical relevance of mouse complex genetics. Eur J Hum Genet 21(11):1191-1196

Sharpless NE, Depinho RA (2006) The mighty mouse: genetically engineered mouse models in cancer drug development. Nat Rev Drug Discov 5(9):741-754

Vandamme TF (2015) Rodent models for human diseases. Eur J Pharmacol 759:84-89

Varga OE, Hansen AK, Sandøe P, Olson IA (2010) Validating animal models for preclinical research: a scientific and ethical discussion. ATLA 38:245-248

Zambrowicz BP, Sands AT (2003) Knockouts model the 100 bestselling drugs-will they model the next 100? Nat Rev Drug Discov 2:38-51 